\title{
Analisis penyebab pernikahan usia anak di Desa Karang Anyar 2 Kabupaten Bengkulu Utara tahun 2020
}

\author{
Lovia Angraini ${ }^{1 *}$, Desi Widiyanti ${ }^{2}$, Wewet Savitri ${ }^{3}$ \\ ${ }^{1}$ Poltekkes Kemenkes Bengkulu
}

\section{INFORMASI ARTIKEL:}

\begin{tabular}{l}
\hline Riwayat Artikel: \\
Tanggal diterima, 24 Agustus 2021 \\
Tanggal direvisi, 24 November 2021 \\
Tanggal dipublikasi, 5 Desember 2021 \\
\hline \\
Kata kunci: \\
Pernikahan Usia Anak; \\
Faktor Internal; \\
Faktor Eksternal;
\end{tabular}

$10.32536 / j$ jki.v5i2.192

Keyword:

Child Marriage;

Internal Factors;

External Factors;

\begin{abstract}
ABSTRAK
Latar belakang: Penyumbang ledakan penduduk salah satunya adalah pernikahan usia anak yaitu pernikahan di bawah usia 18 tahun. Pernikahan anak di dunia tertinggi yaitu negara Niger (75\%). Di Indonesia provinsi dengan pernikahan usia anak tertinggi adalah Sulawesi Barat (19,43\%). Provinsi Bengkulu (14,33\%) urutan ke-1 tertinggi di pulau Sumatera. Data Kantor Urusan Agama (KUA) Argamakmur tahun 2020 terdapat 32 pendaftaran pernikahan usia anak. Dampak pernikahan usia anak pada remaja berdampak negatif baik segi sosial ekonomi, mental/psikologis fisik, trauma bagi kesehatan reproduksi. Faktor terjadinya pernikahan anak adalah faktor internal dan ekternal seperti pendidikan, kemiskinan, pergaulan bebas, budaya dan ekonomi. Tujuan penelitian: untuk mengetahui faktor penyebab pernikahan usia anak di desa Karang Anyar 2 Kabupaten Bengkulu Utara. Metode: jenis penelitian kualitatif deskriptif dengan pendekatan fenomenologi. Teknik pengumpulan data berupa wawancara mendalam (indepth interview) dengan Instrumen penelitian adalah peneliti sendiri. Hasil: menunjukkan bahwa pernikahan anak terjadi karena faktor Internal dan faktor Eksternal. Faktor internal terdiri dari faktor atas kemauan sendiri, Pendidikan, pengetahuan, dan perilaku seks. Sedangkan faktor eksternal terdiri dari faktor budaya dan faktor Ekonomi. Simpulan: faktor yang mempengaruhi pernikahan anak lebih dominan karena faktor internal faktor internal anak
\end{abstract}

Background: One of the contributors to the population explosion is child marriage, namely marriage under the age of 18. The highest child marriage in the world is Niger (75\%). In Indonesia, the province with the highest child marriage age is West Sulawesi (19.43\%). Bengkulu Province (14.33\%) ranks $1^{\text {st }}$ highest on the island of Sumatra. Data from the Argamakmur Religious Affairs Office (KUA) in 2020, there were 32 child marriage registrations. The impact of child marriage on adolescents negatively impacts socio-economic, mental/physical psychological, trauma for reproductive health. Factors that occur in child marriage are internal and external factors such as education, poverty, promiscuity, culture, and economy. Objectives: To determine the factors causing child marriage at Karang Anyar 2 village, North Bengkulu Regency. Methods: This research used descriptive qualitative research with a phenomenological approach. Data collection techniques were taken by indepth interviews with the researcher as the research instrument. Results: the result showed that child marriage occurred due to internal factors and external factors. Internal factors consisted of their own volition, education, knowledge, and sexual behavior. While external factors consisted of cultural factors and economic factors. Conclusion: The predominant factors that influence child marriage are the internal factors, the child's internal factors

\section{Pendahuluan}

Fenomena ledakan penduduk masih terus meningkat di Indonesia, salah satu faktor penyumbang terjadinya ledakan penduduk adalah pernikahan usia anak. Sekitar $23 \%$ perkawinan usia

\footnotetext{
* Korespondensi penulis.

Alamat E-mail: lovia.angraini13@gmail.com
}

anak atau di bawah 18 tahun terjadi di Indonesia (BPS, 2016). Prevalensi pernikahan anak di dunia tertinggi adalah di negara Nigeria yaitu (75\%) (UNICEF dan UNFPA, 2010).

Istilah internasional pernikahan usia anak dikenal dengan child marriage atau early marriage. child marriage atau early marriage adalah 
pernikahan yang terjadi pada anak di bawah usia 18 tahun (UNICEF dan UNFPA, 2010). Batas usia tersebut berdasarkan batas usia perlindungan anak yang ditetapkan dalam konverensi Hak-hak Anak Internasional Convention on the Right of the Child pada tahun 1989 (UNICEF dan UNFPA, 2010).

Pembaharuan usia perkawinan di Indonesia bermula tentang perubahan atas Undang-undang Nomor 23 tahun 2002 tentang Perlindungan Anak, dalam pasal 1 ayat (1) yang dimaksud dengan anak adalah seseorang yang belum berusia 18 (delapan belas) tahun, termasuk anak yang masih dalam kandungan (Nasution, H, 2019).

Hukum mengalami perubahan oleh pemerintah melalui Undang-Undang No. 16 tahun 2019 yang merupakan peralihan dari UndangUndang No. 1 tahun 1974 tentang perkawinan menjadi 19 tahun baik laki-laki maupun perempuan (Karyati, S.dkk, 2019).

Pernikahan yang dilangsungkan pada usia remaja umumnya akan menimbulkan masalah baik secara fisiologis, psikologis dan sosial ekonomi. Dampak nyata dari pernikahan usia muda bagi wanita adalah terjadinya abortus atau keguguran karena secara fisiologis organ reproduksi (khususnya rahim) belum sempurna. Meningkatnya kasus perceraian pada pernikahan usia anak, dan masalah sosial ekonomi pernikahan usia muda terjadi karena biasanya tidak diikuti dengan kesiapan keadaan ekonomi (Romauli dan Vindari, 2012).

Pernikahan usia anak di lingkungan remaja cenderung berdampak negatif baik dari segi sosial ekonomi, mental/psikologis fisik, terutama bagi kesehatan reproduksi sang remaja tersebut (Nad, 2014). Perempuan muda yang sedang hamil, berdasarkan penelitian akan mengalami beberapa hal seperti akan mengalami perdarahan, keguguran dan persalinan yang lama atau sulit (Yenrizal Makmur dalam Nad, 2014).

Perkawinan usia anak di Indonesia pada tahun 2018, menunjukkan $11,21 \%$ perempuan usia $20-24$ tahun menikah sebelum mereka berumur 18 tahun. Angka ini menempatkan Indonesia pada 10 negara dengan angka absolut perkawinan anak tertinggi di dunia (BPS, 2020). Provinsi dengan prevalensi perkawinan anak tertinggi adalah Sulawesi Barat (19,43\%). Provinsi Bengkulu menempati urutan ke-1 pernikahan usia anak di Pulau Sumatera. Hal ini berdasarkan data Susenas tahun 2018 yang menyatakan bahwa perempuan usia 20-24 tahun dengan usia perkawinan pertama kurang dari 18 tahun sebesar 14,33 (Bappenas, BPS, dan PUSKAPA, 2020).

Penelitian yang dilakukan oleh Sunaryanto, $\mathrm{H}$ (2019), bahwa faktor yang melatar belakangi terjadinya pernikahan anak melibatkan faktor internal dan faktor eksternal seperti kemiskinan keluarga, kurangnya pengetahuan, akses internet, dan kurang ketatnya pengawasan lingkungan sosial masyarakat.

Penelitian yang dilakukan Febriawati, dkk (2020) menunjukkan pernikahan usia anak terjadi disebabkan oleh Pendidikan, status sosial ekonomi, teman sebaya dan peran orantua. Fenomena pernikahan anak sering terjadi di kalangan masyarakat kelas bawah, karena akses pendidikan dan kurangnya pemahaman pentingnya pendidikan (Sinaga, 2016).

Pernikahan usia anak pada perempuan akan beresiko mengalami gangguan dalam segala aspek kehidupann. Seperti hubungan seksual yang dipaksakan, terjadinya kehamilan pada usia dini, peningkatan resiko terjangkitnya penyakit HIV, penyakit menular seksual lainnya dan kanker leher rahim (Fadlyana dan Larasaty, 2016).

Dalam aspek kesehatan perempuan yang menikah di usia dini dapat mengalami anemia karena defisiensi nutrisi, depresi, keguguran, BBLR, dan prematur serta stunting. BBLR adalah salah satu faktor yang mempengaruhi kejadian stunting secara langsung (Bappenas, BPS dan PUSKAPA, 2020). Berdasarkan data Kemenkes tahun 2018, angka stunting di provinsi Bengkulu sebesar 29,4\% lebih tinggi dari prevalensi stunting nasional 20,1\% (Hidayah, N. dkk, 2019).

Survei awal yang dilakukan di pengadilan agama Argamakmur, perkara dispensasi perkawinan yang di terima oleh Pengadilan Agama Argamakmur tahun 2020 sebanyak 166 perkara, dengan usia rata-rata pengajuan perkara di usia 17 tahun. Pada tahun 2020 terdapat 32 pendaftaran pernikahan usia remaja di Kantor Urusan Agama (KUA) Argamakmur.

Berdasarkan latar belakang dan data yang telah di kumpulkan, sehingga peneliti tertarik melakukan penelitian dengan judul "Analisis Penyebab Pernikahan Usia Anak di Desa Karang Anyar 2 Kabupaten Bengkulu Utara Tahun 2020". 


\section{Metode penelitian}

Dalam penelitian ini, desain yang di gunakan adalah metode kualitatif deskriptif dengan pendekatan fenomenologi. teknik pengumpulan data berupa wawancara mendalam (Depth interview) dengan cara dialog antar peneliti dengan informan.

Teknik sampling penelitian ini adalah Purposive Sampling, pengambilan sampel dengan cara menetapkan ciri-ciri khusus yang sesuia dengan tujuan penelitian.

Pada penelitian ini jumlah informan utama sebanyak 5 orang dan informan pendukung sebanyak 5 orang, sehingga jumlah seluruh informan yang diwawancara sebanyak 10 orang. Teknik analisis dalam penelitian ini mengacu pada konsep Miles dan Huberman (dalam Lexy J Moleong,2005) yaitu Reduksi Data (Data Reduction), Penyajian Data (Data Display), Penarikan Kesimpulan (Verifikasi)

\section{Hasil dan Pembahasan}

Hasil analisis yang dilakukan terhadap faktor penyebab pernikahan usia anak di desa Karang Anyar 2 Kabupaten Bengkulu Utara adalah faktor Pendidikan, perilaku seks, kemauan diri sendiri, budaya dan ekonomi.

\section{Faktor Pendidikan}

Berdasarkan hasil analisa yang telah dilakukan, jenjang pendidikan wanita yang menikah di usia anak berada di jenjang Sekolah Menengah Pertama (SMP). Hasil penelitian ini menunjukkan bahwa (100\%) wanita yang menikah di usia anak masih di jenjang pendidikan SMP dimana informan utama menuliskan jenjang pendidikan pada batas Sekolah menengah Pertama pada saat sebelum wawancara.

Berdasarkan hasil wawancara dengan pertanyaan mengenai pengetahuan tentang pernikahan usia anak hampir semua informan mengetahui tentang pernikahan usia anak. Hal ini sesuai dengan kutipan di bawah ini yang menyatakan bahwa mereka mengetahui pengertian pernikahan usia anak.

"Seperti nikah di bawa umur misalnya ..."(IU.1)

"Pernikahan dini, pernikahan dini tu setau ambo tu nikah di bawah umur dak..."(IU.2)

"Pernikahan dini adalah pernikahan yang belum cukup umur atau di bawah umur ..."(IU.3)
Namun ada informan yang tidak mengetahui tentang pernikahan usia anak.hal ini sesuai dengan pernyataan di bawah ini:

"Saya kurang tau..."(IU.4)

"Nggak tau saya mbak..."(IU.5)

Menurut pernyataan informan pendukung (orang tua ibu dan ayah),pernikahan usia anak adalah pernikahan di bawah umur. Hal ini sesuai dengan pernyataan di bawah ini :

"La pernikahan dini o,pernikahan di bawah umur, ti sapui umur... Ba nadeak ku ye ti sapui umur nadeak $k u$ ye, awak titik lak nikeak gacang..."(IP.1 Orang Tua)

"Pernikahan di bawah umur... Pernikahan dini itu istilahnya pernikahan yang belum mencampai umur baik laki-laki maupun perempuan gitu..."(IP.2 Orang Tua)

Berdasarkan hasil wawancara dengan pertanyaan mengenai Batasan usia menikah asil penelitian ini menunjukkan bahwa Informan utama mengetahui batasan usia menikah hal ini sesuai dengan pernyataan di bawah ini :

"Sembilan belas taun ke atas..."(IU.1)

"Kalau untuk perempuan?kalau untuk perempuan tu sekitaran 20 tahun kalau dak salah..." (IU.2)

"Batasan usia menikah adalah 19 tahun..."(IU.3)

Menurut pernyataan informan pendukung (KUA, Pengadilan Agama, dan Kepala Desa) batasan usia menikah bagi laki-laki dan perempuan adalah berusia 19 tahun ke atas sesuai dengan pernyataan di bawah ini :

"Normative secara aturan undang-undang nomor 1 tahun 74 wanita, laki-laki minimal 19 tahun. Artinya kalau ditanya ke saya, berapa umur boleh menikah jawabnya itu 19 tahun untuk laki-laki dan 19 tahun untuk perempuan, yo dak..." (IP.3 Kepala KUA Argamakmur)

"...kau la tau kan ini 19 tahun kan.. kalau dulu laki-laki 19 tahun perempuan 16 tahun karno ado aturan baru ini wanita dan laki-laki itu samo samo..."(IP.4 Panitera Pengadilan Agama Argamakmur)

"...undang-undang satu itu usia pernikahan itu yang sewajarnya 21 ke atas... yang diatas 21,22,23 itu lebih baik..."(IP.5 Kepala Desa Karang Anyar 2)

Informan melakukan pernikahan menyebabkan terputusnya pendidikan yang tengah di jalani oleh para informan. Terputusnya pendidikan dikarenakan keinginan sendiri dari informan yang ingin menikah ketimbang melanjutkan jenjang pendidikannya. Keputusan tersebut didasari akan kurangnya pengetahuan yang dimiliki oleh informan mengenai pernikahan dan dampak dari menikah di usia remaja. 
Dari hasil penelitian ini menemukan 2 dari 3 informan utama tidak mengetahui pengertian pernikahan usia anak dan batasan usia pernikahan. Sedangkan informan utama lainnya hanya mengetahui pengertian dan tidak mengetahui sesungguhnya pernikahan usia anak dan dampak dari pernikahan tersebut.

Sejalan dengan penelitian Pratiwi, dkk. (2019) menunjukkan bahwa informan menyatakan tidak mengetahui tentang usia pernikahan yang baik untuk perempuan dan laki-laki, dan tidak mengetahui akibat yang ditimbulkan dari menikah usia anak.

Hasil penelitian yang dilakukan oleh Afrina dan Fatmariza, (2019), menunjukkan bahwa faktor penyebab pernikahan pada usia anak yaitu faktor pendidikan. Hal ini sejalan dengan Penelitian yang dilakukan Febriawati H, Wati N, Arlina (2010) menunjukkan pernikahan usia anak terjadi disebabkan oleh terhentinya pendidikan ( $p_{-}$value $=$ $0,010)$. Sementara pengetahuan tidak menunjukan hubungan yang signifikan dengan pernilahan dini.

Adapun penyebab kurangnya pengetahuan remaja tersebut informan berpendidikan SMP serta umur mereka yang masih di bawah 20 tahun menyebabkan pola pikir mereka belum matang dan dewasa dalam menerima informasi yang diberikan dan juga mengambil keputusan. Sejalan dengan penelitian yang dilakukan oleh Atigsari (2017), menunjukkan bahwa ada hubungan pengetahuan dengan pernikahan usia anak.

Menurut Azwar (2008), struktur sikap terdiri atas tiga komponen yang saling menunjang salah satunya yaitu Komponen kognitif yang merupakan representasi apa yang dipercayai oleh individu pemilik sikap yang berkaitan dengan pandangan, pengetahuan, dan keyakinan. Komponen kognitif berisi kepercayaan stereotipe yang dimiliki individu mengenai sesuatu dapat disamakan penanganan (opini) terutama apabila menyangkut masalah isu atau problem yang kontroversial.

\section{Perilaku seks}

Hasil penelitian ini menemukan bahwa semua informan sudah pernah pacaran saat ditanya mengenai pernah berpacaran dan apakah menikah dengan pacarnya. Hal ini sesuai dengan pernyataan di bawh ini:

\footnotetext{
“Iya..."(IU.1)

“Ehhmm pernah mbak, pernah metean ..."(IU.2)

"Pernah..."(IU.3)
}

\author{
“Pernah..."(IU.4) \\ "Pernah, saya pernah pacaran..."(IU.5)
}

Informan utama dalam pernyataannya mengatakan bahwa menikah dengan pacar mereka. Hal ini sesuai dengan pernyataan di bawah ini:

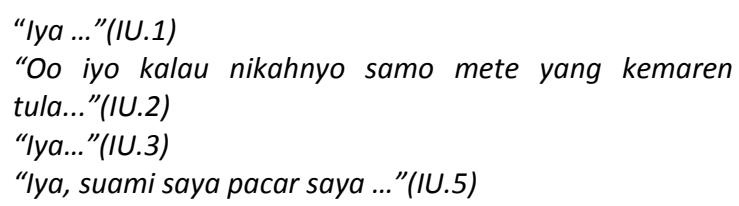

Faktor utama terjadinya pernikahan usia anak yang di akui secara hukum salah satunya adalah kehamilan usia remaja. Alasan menikah dini di usia anak remaja adalah hamil sebelum menikah sehingga pernikahan usia anak menjadi bentuk pertanggung jawaban dari pihak laki-laki (pasangan). Hal ini sesuai dengan pernyataan di bawah ini:

\begin{abstract}
"Oh idak sih kalau dari paksoan dari orang tuo tu idak,cuman pernikahan kami tu atas kemauan kami dewek,kami yang ndak dan jugo kan taula dewek la duluan kan.la hamil luan cak tuna we.."(IU.2)

"Gimana ya,saya menikah karna udah hamil..."(IU.5)
\end{abstract}

Informan pendukung pernyataan orang tua(Ayah) dari informan utama mengatakan alasan menikahkan anaknya Karena anakknya mengalami kecelakaan sebelum menikah. Hal ini sesuai dengan pernyataan berikut:

"Alasannya karena mereka kecelakaan..."(IP.2 Orang Tua)

Pernyataan informan pendukung lainnya adalah karena pergaulan bebas sehingga mengakibatkan kecelakaan berupa hamil di luar nikah. Hal ini sesuai dengan pernyataan di bawah ini:

"Kembali ke faktor ini kan berhubungan dengan pergaulan bebas. Akhirnya hamil di luar nikah(MBA).." (IP.3 Kepala KUA Argamakmur)

Dalam hasil wawancara informan utama memberitahukan bahwa sebelum menikah melakukan persidangan terlebih dahulu. Hal ini sesuai dengan pernyataan di bawah ini:

"Nyo nikah mudo jugo itu tu..Sidang jugo nyo tu kalau idak salah..."(IU.2)

Pernyataan informan pendukung lainnya yang mengatakan anak yang menikah di usia anak harus melakukan sidang dan mendapatkan surat izin dari pengadilan, serta alasan pengadilan 
memperbolehkan menikah adalah karena telah hamil di luar nikah. Hal ini sesuai dengan pernyataan di bawah ini:

"Kalau sekedar orang tu ngomong aku ni ndak nikah, karno kami be duo ni ndak nikah..idak ado,kami belum melakukan hubungan apo-apo misalnyo nah itu idak kami kabuli.. Penyebab nyotu kalau kau ndak tau pertamo karno dio sudah hamil duluan...Nah itulah jadinyo nyo minta dispensasi kawin. Dispensasi tu artinyo di izinkan minta izin ke pengadilan agama..." (IP.4 Panitera Pengadilan Agama)

Pendaftaran pernikahan di KUA harus melalui persidangan baru bisa mendaftar dan menikah.hal ini sesuai dengan pernyataan di bawah ini:

“...Dalam hal ini KUA kita minta hal itu harus izin isbad namanya nikah di pengadilan nanti ada nunggu persidangan dulu setelah persetujuan dari pengadilan barulah baru dapat surat sebenarnya..."(IP.5 Kepala Desa Karang anyar 2)

Orang tua dalam melakukan pengawasan tidak terlalu mengawasi pergaulan anaknya. Sehingga ada orang tua yang tidak mengetahui anaknya berpacaran dan ada yang mengetahui pacar sang anak. Hal ini sesuai dengan pernyataan di bawah ini:

\footnotetext{
"Awei o ba men si alau si minai izin o a,kekuat ne miai izin kulo si lak seusik ngen kekuat ne gen...."(IP.1 Orang Tua)

"Ya sudah, apa namanya,pertama sudah di awasi ya dak sudah di beri tahu.apa namanya orang tua sudah mendidik yang sebaik-baiknya pada anaknya,terus mengarahkanlah memberi tahu.misalnya kalau pergi di suruh pamit kan gitukan...kita tidak bisa mengawasinya selama 24 jam ..."(IP.2 Orang Tua)

"Namen aduk ne o ba,aduk ne uyo ba..." (IP.1 Orang Tua)

"Kalau mau Pergi ngomong. tapi ijinnya mau kenaman mau ke tempat kawan katanya tapi nggak tau saya pacar apa tidak namanya masih pelajarkan..."( IP.2 Orang Tua)
}

Hasil penelitian menunjukkan bahwa faktor yang menyebabkan pernikahan usia anak adalah karena sudah hamil diluar nikah. Kehamilan remaja merupakan cermin dari ketidak mampuan seorang remaja dalam mengambil keputusan pada pergaulannya dengan lawan jenis. Perilaku tersebut karena tidak adanya kontrol diri pada remaja tersebut.

Berdasarkan teori yang dipaparkan oleh Goldfried dan Marbaum kontrol diri merupakan kemampuan untuk mengatur dan mengarahkan bentuk perilaku seseorang ke arah yang positif, termasuk mengatur dan mengarahkan perilaku seksual remaja. Apabila memiliki kontrol diri yang negatif akan berperilaku dan bertindak lebih pada hal-hal yang menyenangkan dirinya, termasuk dengan cara menyalurkan hasrat seksualnya baik dalam bentuk pacaran maupun melakukan hubungan suami istri (Puspitarini S. 2015).

Hasil penelitian yang dilakukan oleh Puspitarini (2015), bahwa ada hubungan minat menikah di usia anak dengan kejadian perilaku seksual pranikah remaja. Sejalan dengan penelitian Yuyun Elistasari (2015), ada hubungan antara perilaku seks pranikah dengan usia menikah pada remaja yang menikah.

Terjadinya $\mathrm{P}$ hamil di luar nikah, karena anakanak melakukan hubungan yang melanggar norma, memaksa mereka untuk melakukan pernikahan usia anak, guna memperjelas status anak yang dikandung (Mubasyaroh 2016).

Evenhuis (2014) menyampaikan perempuan yang tidak sekolah tiga kali lebih mungkin untuk menikah. Artinya, anak perempuan memilih untuk menikah karena alasan kompleks termasuk stigma seks pra nikah dan kehamilan.

Dari hasil penelitian di dapat bahwa untuk anak usia di bawah 19 tahun dalam peraturan perkawinan harus melalui persidangan di pengadilan agama, apabila tidak melakukan persidangan maka pihak KUA tidak menerima pengajuan pendaftaran pernikahan. Dengan kata lain anak tersebut harus mendapatkan izin berupa dispensasi perkawinan. Pasal 7 Ayat (2) memberikan penjelasan alasan mendesak yaitu adalah keadaan tidak ada pilihan lain dan sangat terpaksa harus dilangsungkan perkawinan.

Dalam penjelasan Pasal 7 Ayat menjelaskan bukti-bukti pendukung yang cukup adalah "surat keterangan yang membuktikan bahwa usia mempelai masih di bawah ketentuan undang-undang dan surat keterangan dari tenaga kesehatan yang mendukung pernyataan orang tua bahwa perkawinan tersebut sangat mendesak untuk dilaksanakan". alasan yang seringkali dikabulkannya dispensasi adalah dikarenakan telah terjadi problem sosial pergaulan remaja yang hamil di luar nikah (Zahiranita, Hilma Nur, 2020).

\section{Kemauan diri sendiri}

Hasil penelitian menunjukkan bahwa semua informan utama saat ditanya apakah menikah atas kemauan sendiri mengatakan menikah atas 
kemauan diri sendiri tanpa ada paksaan dari orang tua. Hal ini sesuai dengan pernyataan di bawah ini:

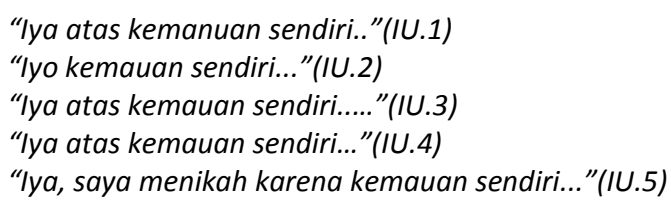

Hal ini sesuai dengan pernyataan dari informan pendukung Orang tua(Ibu) dari informan utama di bawah ini:

"Uku coa ba lak e, si lak, lak nikeak titik gen,co aba ku semayo a..."(IP.1 Orang Tua)

Informan utama dengan pernyataannya mengatakan bahwa alasan menikah dini adalah karena jodoh, saling cinta, dan keinginan untuk menikah. Hal ini sesuai dengan pernyataan di bawah ini:

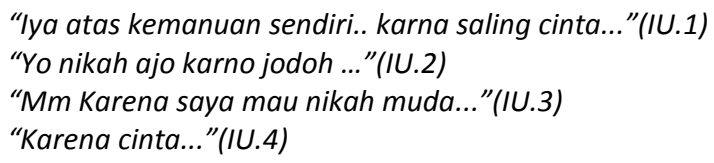

Hasil penelitian menunjukkan bahwa informan utama menikah di usia anak atas kemauan diri sendiri tanpa adanya paksaan dari pihak manapun. Alasan informan utama menikah dini atas dasar saling menyukai antara perempuan dan laki-laki atau atas dasar cinta. Informan utama mengatakan bahwa pernah menjalin hubungan sepasang kekasih atau berpacaran sebelum menikah. Alasan itulah yang membuat informan utama ingin ke jenjang yang lebih serius ke pernikahan walau masih di usia remaja.

Hasil penelitian Dariyo (2003) tentang motivasi menikah dini, cinta dan komitmen merupakan dasar utama pasangan untuk menikah. Banyak pasangan yang melangsungkan pernikahan karena memiliki kecocokan dan kesamaan minat. Secara psikologis, remaja cenderung berfikir secara singkat tanpa memikirkan dampak yang akan terjadi berikutnya.

Salah satu faktor pemicu terbesar perceraian adalah pernikahan dini. Karena bagaimanapun, pernikahan usia muda mengandung resiko besar karena secara mental mereka belum siap untuk memikul tanggung jawab yang besar sebagai sebuah keluarga (Akbar N, 2013).

Hasil penelitian menunjukan orang tua dan lingkungan sosial dalam artian teman sebaya memilik peran terhadap pengambilan keputusan informan menikah usia anak sehingga menjadi terpengaruh karena melihat teman sebayanya sudah menikah (Pratiwi, dkk. 2019).

Mengingat dalam penelitian menunjukkan bahwa tempat tinggal dari informan satu dengan informan lainnya tidak terlalu jauh dengan kata lain sangat dekat satu sama lainnya. Sejalan dengan hasil penelitian Khaparistia (2015) mengenai faktor-faktor penyebab terjadinya pernikahan usia muda menunjukkan remaja terpengaruh lingkungan sosial, dalam hal ini anak mengikuti teman sebayanya yang telah menikah usia muda.

\section{Budaya}

Hasil Penelitian menunjukkan bahwa tidak ada adat atau kebudayaan yang mengharuskan untuk pernikahan usia anak pada saat di wawancara. Hal ini sesuai dengan pernyataan di bawah ini:

"Oh idak sih ..."(IU.2)

"Nggak, mau nikah aja.."(IU.4)

Hal ini juga sesuai dengan pernyataan informan pendukung (KUA dan Kepala Desa) dengan pernyataan di bawah ini:

\footnotetext{
“...katakanlah agak minim karena dareah kita ini untuk penduduknya yang asli tapi kalau udah banyak pendatang udah karna pengaruh umum pendidikan dan pengalaman itu agak kurang..."(IP.5 Kepala Desa Karang anyar 2)

"Kalau sayo raso idak lagi,kalau dulu anaknyo jangan nian sampai 17 tu. La jadi gadis tu jadi kecek'an orang..." (IP.3 Kepala KUA Argamakmur)
}

Dari hasil penelitian tidak ada budaya di lingkungan sekitar yang mengharuskan menikah di usia anak seperti akan takut anaknya atau seorang gadis menjadi perawan tua dan sebagainya. Hal ini dikarenakan di wilayah penelitan masyarakat sudah bercampur dengan masyarakat pendatang dari daerah lain tidak hanya penduduk lokal saja. Penduduk di tempat penelitian bermayoritas bersuku Rejang dan dalam adat Rejang tidak ada keharusan menikah di usia muda.

Hasil penelitian sejalan dengan penelitian Rahma (2014) yang menyatakan bahwa tidak terdapat hubungan ( $p$-value $=0,321$ ) antara budaya dengan pernikahan usia dini. Hasil ini bertolak belakang dengan penelitian yang dilakukan oleh Rahman, dkk (2015), menunjukkan bahwa pernikahan dini terjadi karena adat budaya daerah yang menjadi kebiasaan. 


\section{Ekonomi}

Hasil penelitian menunjukkan bahwa semua informan utama tidak melakukan pernikahan usia anak atas dasar faktor ekonomi seperti kemiskinan dan kurang mampu. Hal ini sesuai dengan pernyataan di bawah ini:

\footnotetext{
"Nggak ada paksaan cuman mau kemauan sendiri aja..."(IU.1)

"Oh idak sih kalau dari paksoan dari orang tuo tu idak,cuman pernikahan kami tu atas kemauan kami dewek,kami yang ndak..."(IU.2)

"Nggak mau nikah aja..."(IU.3)

"Nggak ada faktor apa-apa keinginan sendiri..."(IU.4)

"Mm,,nggak ada sih mbak, Cuma teman2 emang banyak yang udah nikah.jadi, ya gitu mau nikah juga..."(IU.5)
}

Dalam hal ini informan pendukung memiliki pendapat bahwa masih ada faktor ekonomi yang menjadi alasan baik orang tua maupun anak sebagai pelaku pernikahan usia anak $\mathrm{Hal}$ ini sesuai dengan pernyataan di bawah ini:

"Kebanyakan itu kalau faktor ekonomi saya rasa tidak
ada-ada tapi tidak terlalu mendominasi..." (IP.3 Kepala
KUA Argamakmur)
"Yang keduo mungkin faktor orang tuonyo dak sanggup
untuk membiayai anaknyo lagi..."(IP.4 Panitera
Pengadilan Agama)
"...di desa juga memang ada juga memang keadaan
orang tua juga yang tidak mampu...."(IP.5 Kepala Desa
Karang Anyar 2)

Pernikahan usia muda yang terjadi disebabkan karena alasan mengurangi kebutuhan ekonomi keluarga. Faktor ini berhubungan dengan rendahnya tingkat ekonomi keluarga. Orang tua tidak memiliki kemampuan untuk memenuhi kebutuhan keluarga sehingga orangtua memilih untuk mempercepat pernikahan anaknya, terlebih bagi anak perempuan sehingga dapat mengurangi pemenuhan kebutuhan keluarga (Landung dkk, 2009). Hal ini sejalan dengan Jannah (2012) yang menjelaskan bahwa para orang tua yang menikahkan anaknya pada usia muda mengganggap bahwa dengan menikahkan anaknya, maka beban ekonomi keluarga akan berkurang satu.

Hasil penelitian yang dilakukan peneliti tidak menunjukkan bahwa permasalahan ekonomi menjadi alasan informan utama menikah di usia anak. Dalam penelitian yang di lakukan 2 dari 3 informan merupakan keluarga yang orang tua sebagai petani yang berpenghasilan cukup untuk memenuhi kebutuhan sehari-hari saja. Sedangkan
3 informan berlatar belakang keluarga yang memiliki penghasilan menengah atau sebagai guru dan PNS.

Walaupun demikian permasalahan ekonomi masih menjadi alasan di tempat penelitian untuk informan utama ataupun orang tua menikahkan anaknya di usia muda namun tidak banyak. Artinya bagi anak tidak ada ketakutan untuk tidak hidup layak pada umumnya sesuai dengan standar desa. Akan tetapi dari aspek lain seperti psikologis, pendidikan dan kebutuhan interaksi sosial anak akan terganggu. Dalam banyak literatur pernikahan anak di negara berkembang dianggap salah satu faktor yang merugikan dan merampas kehidupan sosial dan ekonomi masa depan jutaan anak (Malhotra, 2010).

\section{Simpulan}

Berdasarkan Analisis Penyebab Pernikahan Usia Anak di Desa Karang Anyar 2 Kabupaten Bengkulu Utara dapat disimpulkan bahwa faktor yang melatar belakangi terjadinya pernikahan anak melibatkan faktor internal individu dan faktor eksternal. Faktor Internal berupa perilaku seks pada anak remaja (pergaulan bebas), kehamilan di luar pernikahan, faktor keinginan sendiri, dan faktor Pendidikan. Faktor Eksternal berupa paksaan orang tua, faktor ekonomi dan budaya, namun tidak terlalu mempengaruhi terjadinya pernikahan usia anak di desa Karang Anyar 2.

\section{Daftar Pustaka}

Agtikasari, N. (2017). Hubungan Pengetahuan Tentang Pernikahan Usia Dini Dengan Sikap Siswa Terhadap Pernikahan Usia Dini Di Sma Negeri 2 Banguntapan Tahun 2015. Jurnal Ners Dan Kebidanan (Journal Of Ners And Midwifery), 4(1), 051-055.

Akbar, N. (2013). Faktor Penyebab Perkawinan Di Bawah Umur Dilihat Dari Hukum Islam Dan Hukum Adat (Doctoral Dissertation, Universitas Islam Negeri Alauddin Makassar).

Azwar, S. 2008. Sikap manusia: Teori dan pengukurannya (ed.4). Yogyakarta: Pustaka Pelajar.

BPS. 2016. "Analisis Data Perkawinan Usia Anak Di Indonesia." 
BPS, BAPPENAS, dan PUSKAPA, 2020. "Pencegahan Perkawinan Anak Percepatan Yang Tidak Bisa Ditunda." 1-3.

Dariyo, 2003. Psikologi Perkembangan Dewasa Muda. Jakarta: PT Gramedia Widiasarana.

Elitasari Y, Astutsi DA. 2015. Hubungan Perilaku Seks Pranikah Dengan Usia Menikah Pada Remaja yang Menikah di Tahun 2015 di Kecamatan Playen Kabupaten Gunungkidul. Skripsi tidak dipublikasikan. Digilib at UNISA Yogyakarta.

Evenhuis, M. 2014. 'Just Married, Juat a Child': Child Marriage in the Indonesian-Pacific Region. Melbourne: Plan International Australia

Fadlyana, E., \& Larasaty, S. (2016). Pernikahan Usia Dini Dan Permasalahannya. Sari Pediatri, 11(2), 136-41.

Febriawati H, Wati N, Arlina. 2010. Faktor Faktor yang Berhubungan Dengan Pernikahan Usia Dini Di Kecamatan Semidang Alas Maras Jabupaten Seluma. Avicenna: Jurnal IImiah, Vol 15 (1): 43-53

Hidayah, N.Dkk. (2019). Hubungan Pola Asuh Dengan Kejadian Stunting (Rekomendasi Pengendaliannya Di Kabupaten Lebong). Riset Informasi Kesehatan, 8(2), 140-151.

Karyati, Sri, Baiq Farhana Kurnia Lestari, And Arya Sosman. 2019. "Kebijakan Pencegahan Pernikahan Anak Di Provinsi Ntb Pasca Berlakunya Uu No.16 Tahun 2019 Tentang Perubahan Uu No.1 Tahun 1974 Tentang Perkawinan." Jurnal Unizar Law Review 2(2):136-143.

Khaparistia E, 2015. Faktor faktor Penyebab Terjadinya Pernikahan Usia Muda Studi Kasus di Kelurahan Sawit Seberang Kecamatan Sawit Seberang Kabupaten

Landung (2009). Studi Kasus Kebiasaan Pernikaha Usia Dini pada Masyarakat Kecamatan Sanggalangi Kabupaten Tana Toraja. Media Kesehatan Masyarakat Vol $4(5), 89-94$

Malhotra, Naresh (2009). Riset Pemasaran Pendekatan Terapan, Edisi keempat, Jilid 1. Jakarta :PT Indeks
Mubasyaroh.2016.“Analisis Faktor Penyebab Pernikahan Dini Dan Dampaknya Bagi Pelakunya." Jurnal Pemikiran Dan Penelitian Sosial Keagamaan 7(2):385-411.

Musalim.2017. "Pernikahan Usia Dini Di Desa Bukit Payung Kecamatan Bangkinang Kabupaten Kampar." 4(1):1-14.

Nad. 2014. Beragam Efek Buruk Pernikahan Dini. Dapat diunduh dari:

http/\%20www.beritasatu.com/ gaya-hidup/177423-beragam-efek-burukpernikahan-dini.html

Nasution, H. (2019). Pembaharuan Hukum Keluarga Islam Tentang Usia Perkawinan Di Indonesia (Studi Atas Undang-Undang Nomor 16 Tahun 2019 Tentang Perubahan Undang-Undang Nomor 1 Tahun 1974 Tentang Perkawinan) (Doctoral Dissertation, Universitas Islam Negeri Sumatera Utara).

Pratiwi, Dkk. 2019. “Analisis Pernikahan Usia Dini Di Kabupaten Bengkulu Tengah Tahun 2017." Jurnal Kesmas Asclepius 1(1):14-24.

Puspitarini, S. 2015. Hubungan Minat Menikah Dini Dengan Kejadian Perilaku Seksual Pranikah Remaja Kelas XI di SMK PGRI Sentolo KUlonprogo. Skripsi tidak dipublikasikan. Digilib at UNISA Yogyakarta.

Rahman. F., Syahadatina, M., Aprillisya R, Afika HD, 2015. Kajian Budaya Remaja Pelaku Pernikahan Dini di Kota Banjarbaru Kalimantan Selatan. Media Kesehatan Masyarakat Indonesia. Vol 11 (2).

Rahma, E. 2014. Faktor Faktor Yang Mempengaruhi Kejadian Pernikahan Usia Dini Pada Wanita Umur Di Bawah 20 Tahun di Kecamatan Kubung Kabupaten Solok Tahun 2013. Skripsi tidak di publikasikan. Scholar.unand.ac.id

Romauli, S., Vindari, A. 2012. Kesehatan Reproduksi Buat Mahasiswa Kebidanan Yogyakarta: Nuha Medika

Sinaga,D.2016.Fenomena Pernikahan Dini Dan Solusinya.Diambil Dari Cnn Indonesia:https://Student.Cnnindonesia.Co m/Inspirasi/20160318142526-322118315/Fenomena-Pernikahan-DiniDansolusinya/ 
Sunaryanto,Heri. 2019. "Analisis Sosial-Ekonomi Faktor Penyebab Perkawinan Anak Di Bengkulu: Dalam Perspektif Masyarakat Dan Pemerintah (Studi Kasus Di Kabupaten Seluma)." Jurnal Sosiologi Nusantara 5(1):22-42.

UNICEF And UNFPA, 2010. Marrying Too Young. Vol. 11. New York: Unitednations Population Fund Unfpa.
Yanti, Afrina dan Fatmariza, 2019. Fenomena Pernikahan Usia Anak di Pesisir Selatan. Jurnal of Civic Education. Vol 2 No 3. DOI: https://doi.org/10.24036/jce.v2i4.226

Zahiranita, Hilma Nur (2020). Dispensasi Nikah Pada Penetapan No. 758/Pdt. $\mathrm{P} / 2019 / \mathrm{Pa}$. Js Pasca Lahirnya Uu No. 16 Tahun 2019. Bs Thesis. Fakultas Syariah Dan Hukum Universitas Islam Negeri Syarif Hidayatullah Jakarta. 